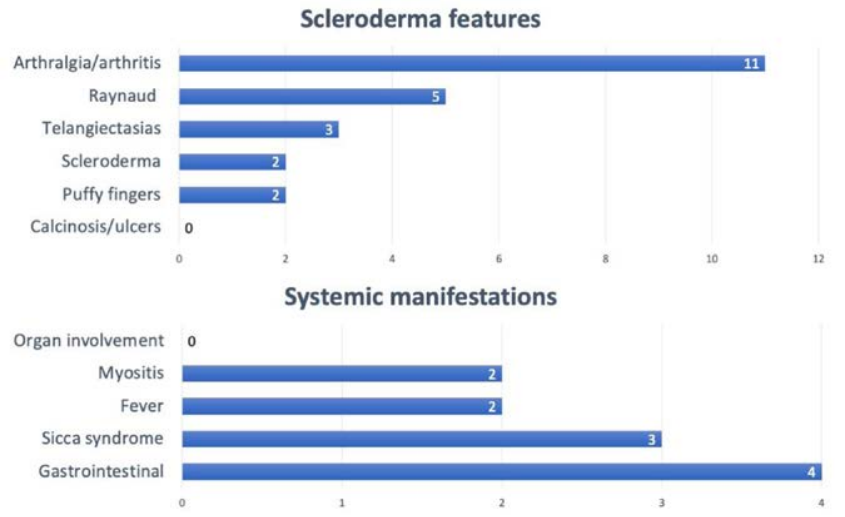

Figure 1. Clinical characteristics of anti-NOR90 Ab patients.

Conclusion: In our case series anti-NOR90 Ab were associated with multiple rheumatic diseases with heterogeneity of clinical manifestations. We did not observe a further progression to SSc or presence of organ involvement or severe scleroderma, so these autoantibodies could be related with a favorable prognosis. In contrast with previous reports, a striking association with cancer has been detected in our population.

Table 1. Demographic characteristics and main diagnoses of anti-NOR90 positive patients.

\begin{tabular}{|c|c|}
\hline Characteristics & Total Anti-NOR90: 26 patients \\
\hline Sex, $\mathrm{n}$ & 19 women/ 7 men \\
\hline Age, mean (years) & 58,9 IQR $[46,3-72,2]$ \\
\hline Race, $\mathrm{n}$ & Asian: 1 ; Hispanic: 7 ; Caucasian: 18 \\
\hline Smoker, n & 3 \\
\hline Positive ANA (>1/160), $n$ & 24 \\
\hline Pattern, $n$ & $\begin{array}{l}7 \text { Homogeneous, } 4 \text { Nucleolar, } 4 \text { Speckled, } \\
1 \text { Centromere, } 5 \text { Speckled -nucleolar, } 3 \\
\text { Homogeneous-nucleolar. }\end{array}$ \\
\hline Positive ENA, $n$ & $\begin{array}{l}2 \text { Anti-SSA-Ro52 and Ro60, } 1 \text { anti-RNP } \\
\text { and anti-Sm }\end{array}$ \\
\hline $\begin{array}{l}\text { Systemic sclerosis } \\
\text { autoantibodies, } \mathrm{n}\end{array}$ & $\begin{array}{l}\text { - Anti-Ku: } 7 \\
\text { - Anti-U3RNP (Fibrilarin): } 6 \\
\text { - Anti-RNA polymerase III: } 5 \\
\text { - Anti Th/To: } 4 \\
\text { - Anti-centromere: } 4 \text { (CENP B +/- CENPA) } \\
\text {-Anti-topoisomerase I: } 2 \\
\text { - Anti-Ro52: } 3 \\
\text { - Anti-PM-Scl: } 3\end{array}$ \\
\hline Main diagnosis, $\mathrm{n}$ & $\begin{array}{l}12 \text { Rheumatic diseases: } \\
2 \text { systemic Sclerosis ( } 2 \text { limited/0 diffuse) } \\
1 \text { rheumatoid arthritis } \\
1 \text { LES } \\
1 \text { Sjögren's syndrome, } \\
3 \text { undifferentiated conective tissue disease } \\
2 \text { overlap ( } 1 \text { Sjögren + LES, } 1 \text { Sjögren + MCTD 1) } \\
\text { s: } 1 \text { morphea, } 1 \text { cutaneous graft versus host disease }\end{array}$ \\
\hline Neoplasm, $\mathrm{n}$ & $\begin{array}{l}\text { 6: } 2 \text { solid organ cancer (bladder, kidney), } 1 \text { lung } \\
\text { adenocarcinoma, } 1 \\
\text { multiple myeloma, } 1 \text { acute myeloid leukemia: } 1 \text { basal } \\
\text { cell carcinoma. }\end{array}$ \\
\hline
\end{tabular}

$\overline{\text { Abbreviations: LES: systemic lupus erythematosus; MCTD: mixed connective tissue disease }}$

Disclosure of Interests: None declared

DOI: 10.1136/annrheumdis-2021-eular.1477

\section{AB0428 ULTRASOUND ASSESSED NAIL BED THICKNESS AS AN EARLY SCREENING MARKER FOR INTERSTITIAL LUNG DISEASE IN SCLERODERMA}

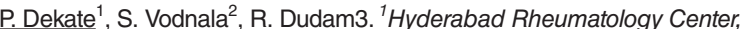
Rheumatology, Hyderabad, India; ${ }^{2}$ Hyderabad Rheumatology Center, Radiology, Hyderabad, India; ${ }^{1}$ Hyderabad Rheumatology Center, Rheumatology, Hyderabad, India

Background: Interstitial lung disease (ILD) is the most frequent pulmonary manifestation of scleroderma and is seen in $80 \%$ of the patients with diffuse and in $20 \%$ of the limited forms of scleroderma. ${ }^{1}$ Even seen in early stages of the disease with varying degrees of severity, it does not correlate with the clinical manifestations. ${ }^{2}$ Hence, it is difficult to select patients for ILD screening based on symptoms. Digital clubbing is a common feature of ILD and has been associated with poor prognosis. ${ }^{3}$ Objectives: To assess the ultrasound measured nail bed thickness (NBT) in cases of scleroderma as a screening marker to detect ILD and its inter-digital variation.
Methods: A prospective observational study involving 15 patients each of scleroderma with ILD, without ILD and controls visiting our clinic from August 2020 to December 2020 were included. The presence of ILD was confirmed by HRCT thorax. Patients with a history of smoking, alcohol intake or pre-existing cardio-respiratory illnesses were excluded. Ultrasound assessed NBT was calculated using Philips affiniti 70 eL18-4 probe. A total of 436 nail beds were recorded (142 of scleroderma with ILD, 144 of scleroderma without ILD and 150 of control group). 14 nails were excluded due to trauma. Statistical analysis was done using ANOVA test. Results were considered significant at $p$ value $<0.05$ Results: On comparing nail bed thickness among scleroderma with ILD, scleroderma without ILD and control groups, the difference in NBT was statistically significant in all the three groups, except for left $1^{\text {st }}$ finger (Table 1). NBT's among scleroderma patients without ILD and control group did not show significant difference between the two groups. Whereas, when scleroderma patients with ILD were compared with control group, statistical significance were found $(p<0.001)$ in all the fingers of both the hands, except 1st and 2nd finger of left and right hand respectively. On comparing NBT's among individual fingers of right hand in patients of scleroderma with ILD and without ILD, a statistically significant difference among the two groups in $2 n d(p=0.002)$, 4th $(p=0.009)$ and 5th finger $(p=<0.001)$ was noted. In left hand, same fingers had statistically significant difference $(p<0.001)$.

Conclusion: Patients of scleroderma with ILD are predisposed for an increase in the NBT, which can be detected using ultrasound. Thus, an increased NBT may have a role in early screening for the detection of ILD in scleroderma patients. Further studies with large patient data should be done to look at ultrasound assessed NBT as it may be utilized as a marker for ILD in scleroderma, as a widely available and an inexpensive tool.

\section{REFERENCES:}

[1] Boin F, Wigley FM. Clinical Features and Treatment of Scleroderma. In: Firestein G, Budd R, Sherine E, et al, eds. Kelley's Textbook of Rheumatology. Philadelphia, PA: Elsevier; 2013:1366-1403.

[2] Hassan RI, et al. Lung ultrasound as a screening method for interstitial lung disease in patients with systemic sclerosis. JCR: Journal of Clinical Rheumatology. 2019;25(7):304-7.

[3] T.E. King Jr., J.A. Tooze, M.I. Schwarz, K.R. Brown, R.M. CherniackPredicting survival in idiopathic pulmonary fibrosis: scoring system and survival model Am. J. Respir. Crit. Care Med., 164 (7) (2001), 1171-81.

Table 1. Nail bed thickness in patients of scleroderma with ILD, without ILD and control groups.

\begin{tabular}{|c|c|c|c|c|c|c|c|c|}
\hline & \multirow[b]{2}{*}{ Finger } & \multicolumn{2}{|c|}{$\begin{array}{c}\text { Scleroderma } \\
\text { with ILD } \\
n=15\end{array}$} & \multicolumn{2}{|c|}{$\begin{array}{c}\text { Scleroderma } \\
\text { without ILD } \\
\text { n=15 }\end{array}$} & \multicolumn{2}{|c|}{$\begin{array}{l}\text { Control } \\
n=15\end{array}$} & \multirow[b]{2}{*}{ p-value } \\
\hline & & Mean & SD & Mean & SD & Mean & SD & \\
\hline \multirow[t]{5}{*}{ Right } & $1^{\text {st }}$ & 1.86 & 0.239 & 1.71 & 0.081 & 1.69 & 0.107 & 0.021 \\
\hline & $2^{\text {nd }}$ & 1.73 & 0.303 & 1.50 & 0.079 & 1.61 & 0.108 & 0.003 \\
\hline & $3^{\text {rd }}$ & 1.89 & 0.200 & 1.75 & 0.091 & 1.50 & 0.131 & $<0.001$ \\
\hline & $4^{\text {th }}$ & 1.80 & 0.263 & 1.39 & 0.147 & 1.35 & 0.078 & $<0.001$ \\
\hline & $5^{\text {th }}$ & 1.80 & 0.119 & 1.24 & 0.095 & 1.29 & 0.069 & $<0.001$ \\
\hline \multirow[t]{5}{*}{ Left } & $1^{\text {st }}$ & 1.98 & 0.442 & 1.72 & 0.084 & 1.68 & 0.050 & 0.078 \\
\hline & $2^{\text {nd }}$ & 1.82 & 0.123 & 1.57 & 0.125 & 1.57 & 0.092 & $<0.001$ \\
\hline & $3^{\text {rd }}$ & 2.05 & 0.309 & 1.76 & 0.078 & 1.42 & 0.109 & $<0.001$ \\
\hline & $4^{\text {th }}$ & 1.92 & 0.246 & 1.36 & 0.130 & 1.35 & 0.107 & $<0.001$ \\
\hline & $5^{\text {th }}$ & 1.81 & 0.158 & 1.15 & 0.368 & 1.23 & 0.103 & $<0.001$ \\
\hline
\end{tabular}

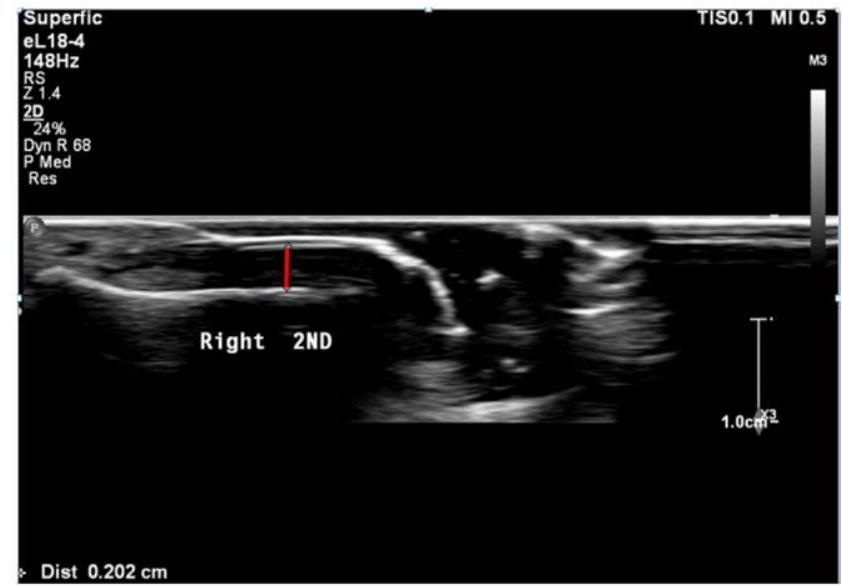

Figure 1. NBT measurement of right 2nd finger in scleroderma patient with ILD on ultrasound 
Disclosure of Interests: None declared

DOI: 10.1136/annrheumdis-2021-eular.1585

\section{AB0429 BELFAST TRUST EXPERIENCE OF IDIOPATHIC INFLAMMATORY MYOPATHIES}

S. Loughrey ${ }^{1}$, A. Herron ${ }^{1}$, M. Mchenry ${ }^{1}$, E. Ball' ${ }^{1}{ }^{1}$ Musgrave Park Hospital, Rheumatology, Belfast, United Kingdom

Background: The Idiopathic Inflammatory Myopathies (IIM) are a heterogeneous group of diseases where there is a growing field of knowledge and experience. Presentation is usually of onset of muscle weakness in combination with typical muscle biopsy findings and specific serum autoantibodies. There is a significant morbidity and mortality associated with IIM, due to its potential systemic nature, associated malignancy risk and side effects of immunosuppressive therapy1. There is no published guideline on management of IIM, with treatment limited to best practice experience.

Objectives: Review Belfast Trust experience of Adult IIM from 2009-2020

Methods: Review of Electronic Records of 18 patients diagnosed with IIM between 2009-2020

Results: 18 patients diagnosed with IIM. Mean age at diagnosis is 64 , with age range of 46-83. Mean duration of treatment is 4 years. 14 patients are in remission, 2 have active disease and 2 are deceased with cause of death unrelated to IIM.

Muscle Biopsy was performed in 17 patients. 11 patients biopsies were diagnostic and 6 were supportive. Of the patients with DM who did not have diagnostic muscle biopsies, all 3 had diagnostic skin biopsies. Of 6 patients with a negative

Table 1. Overview of diagnosis and treatment of patients with IIM. PM - Polymyositis DM - Dermatomyositis IBM - Inclusion Body Myositis IMNM Immune Mediated Necrotising Myositis EP - Extended Panel ILD Interstitial Lung Disease RA - Rheumatoid Arthritis RTx - Rituximab IVIG - Intravenous Immunoglobulin MTX - Methotrexate AZA -

Azathioprine MMF - Mycophenolate Mofetil SLZ - Sulphasalazine HLQ Hydroxychloroquine

\begin{tabular}{|c|c|c|c|c|c|c|c|c|c|}
\hline Diagnosis & $\begin{array}{l}\text { ANA/Extra } \\
\text { muscular }\end{array}$ & $\begin{array}{c}\text { Failed/ } \\
\text { Intolerance }\end{array}$ & RTxI & IVIGI & & IZAMMF & $\begin{array}{l}\text { Ciclos- } \\
\text { porin }\end{array}$ & $\begin{array}{l}\text { SLZI } \\
\text { HLQ }\end{array}$ & $\begin{array}{l}\text { Prednisolone } \\
\text { duration } \\
\text { (months) }\end{array}$ \\
\hline PM & Jo-1 Ro & AZA & & & & $\mathrm{x}$ & & & 18 \\
\hline PM & $\begin{array}{c}\text { Jo-1 } \\
\text { Myocarditis }\end{array}$ & AZA & $x$ & $x$ & & & $x$ & & 12 \\
\hline PM & $\begin{array}{c}\text { Negative. No } \\
\text { EP }\end{array}$ & $\begin{array}{c}\text { AZA/MMF/ } \\
\text { RTx }\end{array}$ & & & $x$ & & & & Maint. 3mg \\
\hline PM & $\begin{array}{c}\text { Negative. No } \\
\text { EP } \\
\text { ILD }\end{array}$ & & & & $x$ & & & & 22 \\
\hline PM & $\begin{array}{c}\text { Jo-1 } \\
\text { ILD, Mechanic } \\
\text { Hands }\end{array}$ & Mtx/MMF & $x$ & & & & & $x$ & Maint. $7 \mathrm{mg}$ \\
\hline PM & $\begin{array}{c}\text { Negative. No } \\
\text { EP }\end{array}$ & & & & & $\mathrm{x}$ & & & 36 \\
\hline PM & $\begin{array}{c}\text { Negative. No } \\
\text { EP }\end{array}$ & & $x$ & & & & & & $\begin{array}{c}18, \text { reducing } \\
\text { dose }\end{array}$ \\
\hline PM & $\begin{array}{c}\text { Negative. No } \\
\text { EP }\end{array}$ & & $x$ & & $\mathrm{x}$ & & & & Maint. 5mg \\
\hline PM & $\begin{array}{c}\text { Ro } \\
\text { ILD, } \\
\text { Dysphagia }\end{array}$ & & & $x$ & & & & & $\begin{array}{c}\text { 6, reducing } \\
\text { dose }\end{array}$ \\
\hline DM & $\begin{array}{l}\text { MDA5, Ro } \\
\text { Rash, ILD }\end{array}$ & AZA & $x$ & $x$ & & $X$ & & & 18 \\
\hline DM & $\begin{array}{l}\text { Mi2 } \\
\text { Rash }\end{array}$ & Mtx & $x$ & & & $X$ & & & 20 \\
\hline DM & $\begin{array}{l}\text { PM-SCL } \\
\text { Rash }\end{array}$ & & & & & & & & Deceased \\
\hline DM & $\begin{array}{l}\text { Ro52 } \\
\text { Sicca }\end{array}$ & & $x$ & & & & & & $\begin{array}{c}6, \text { reducing } \\
\text { dose }\end{array}$ \\
\hline DM & $\begin{array}{l}\text { MDA5, NXP2 } \\
\text { Rash }\end{array}$ & & $x$ & & & $x$ & & & Maint, $12.5 \mathrm{mg}$ \\
\hline $\begin{array}{l}\text { DM- } \\
\text { Amyopathic }\end{array}$ & $\begin{array}{l}\text { SAE } \\
\text { Rash }\end{array}$ & MTx & $x$ & $x$ & & $\mathrm{X}$ & & & Deceased \\
\hline IBM & Ro/La & & $\mathrm{x}$ & $x$ & & & & $x$ & $\begin{array}{c}\text { Unknown dura- } \\
\text { tion. Now } \\
\text { stopped }\end{array}$ \\
\hline IMNM & HMGCR & & & & $\mathrm{x}$ & & & & 12 \\
\hline IMNM & HMGCR & & $x$ & $x$ & $x$ & & & & $\begin{array}{c}18, \text { reducing } \\
\text { dose }\end{array}$ \\
\hline
\end{tabular}

ANA, 5 had a muscle biopsy performed (diagnostic in 4 patients and supportive in 1 patient.)

Conclusion: Extended myositis panels have only readily become available in the Belfast Trust in recent years. This has enhanced patients phenotypes and vigilance for extra-muscular complications. There is a recognised elevated risk of cancer in patients with IIM2. In our patients, with a mean disease duration of 4 years, none have developed malignancy. All of our patients had a tissue sample obtained, either muscle or skin. In the Belfast Trust, Rheumatologists perform muscle biopsies and all of the samples contributed to diagnosis. A limitation of diagnostic tests is restricted access to EMGs. We introduced a variety of DMARDs to limit exposure to steroids. $50 \%$ of our patients are in remission and off steroids. The only biologic we used was Rituximab. In contrast to other rheumatological conditions, there is no published protocol for administration of Rituximab in IIM. For patients with refractory disease, IVIG was used in the short term to allow for introduction of alternative immunosuppressants to maintain remission. This review highlights the complex nature of this group of diseases, and our experience with a variety of treatment options We have diagnosed and treated 18 patients, and although we have experience with the medications used to treat IMM further work is needed to establish evidence based treatment.

\section{REFERENCES:}

[1] Barsotti, Lundberg et al 'Current Treatment for Myositis' Curr Treatm Opt Rheumatol vol 4 (4) 2018 p299-315 2. Kang et al 'Temporal relationship between cancer and myositis identifies two distinctive subgroups of cancers: impact on cancer risk and survival in patients with myositis' Rheum vol 55 (9) 2016 p1631-1641

Disclosure of Interests: None declared

DOI: 10.1136/annrheumdis-2021-eular.1602

\section{AB0430 CONTRIBUTION OF SCLERODERMA/MYOSITIS- RELATED ANTIBODIES DETECTED BY IMMUNOBLOT TO THE DIAGNOSIS OF SYSTEMIC AUTOIMMUNE RHEUMATIC DISEASES IN 134 PATIENTS FROM A SINGLE REFERRAL CENTER}

D. Prieto-Peña ${ }^{1}$, B. Atienza-Mateo ${ }^{1}$, M. A. González-Gay ${ }^{1}$, R. Blanco ${ }^{1}$, M. Lopez-Hoyos ${ }^{2} .{ }^{1}$ Hospital Universitario Marques de Valdecilla, IDIVAL, Rheumatology, Santander, Spain; ${ }^{2}$ Hospital Universitario Marques de Valdecilla, IDIVAL, Immunology, Santander, Spain

Background: Immunoblot assays are increasingly used in clinical practice as part of the diagnostic armamentarium of systemic autoimmune rheumatic diseases (SARDs)

Objectives: To assess the contribution of an extended scleroderma/myositis-related antibodies $(\mathrm{Ab})$ determination by immunoblot to the diagnosis of patients with SARDs.

Methods: We reviewed all medical records of patients with positive scleroderma/ myositis-related $\mathrm{Ab}$ line blot determinations (Euroimmune AG, Lübeck, Germany) in our center from November 2017 to September 2020. These assays were requested due to high suspicion of SARDs in patients presenting with non-specific symptoms.

Results: 134 patients (37men/97women; mean age $59.6 \pm 14.8$ years) were positive for at least $1 \mathrm{Ab}, 25$ of them were positive for 2 Abs. Main clinica features at the time of immunoblot requests were: arthralgia/arthritis $(n=88)$, Raynaud's phenomenon $(n=59)$, rash $(n=27)$, sicca syndrome $(n=14.9 \%)$ myopathy $(n=18)$. During follow-up, 28 patients were diagnosed with undifferentiated connective tissue disease (UCTD), 26 scleroderma, 23 overlap myositis, 18 interstitial pneumonia with autoimmune features (IPAF), 8 other inflammatory diseases, 8 Sjögren's syndrome, 7 systemic lupus erythematosus, 5 dermatomyositis, 1 necrotizing myositis. In 10 patients the diagnosis of SARD was finally ruled out (Figure 1). Interstitial lung disease (ILD) was present in 50 patients, being particularly frequent in those with anti-PL12, anti-PL7 and anti-MDA5 Abs. Cancer was detected in $9(6.7 \%)$ patients, 6 of them were anti-Ro52 + (Table 1).

Conclusion: Immunoblot assays are of great help in the diagnosis of patients with high clinical suspicion of SARDs. While some Abs, such as anti-Ro52, anti-Ku and anti-PMScl75/100, remain to be nonspecific, other Abs including anti-PL12, anti-PL7 or anti-MDA5 are particularly helpful in detecting SARDs patients with associated ILD. 